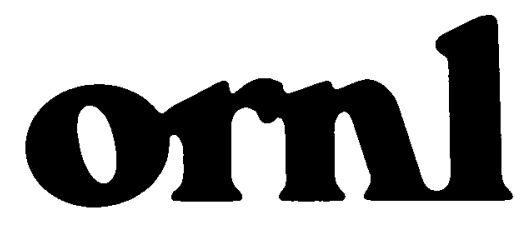

OAK RIDGE NATIONAL LABORATORY

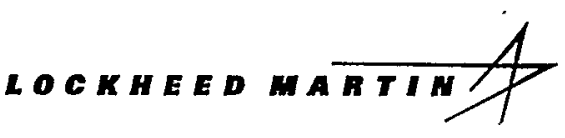

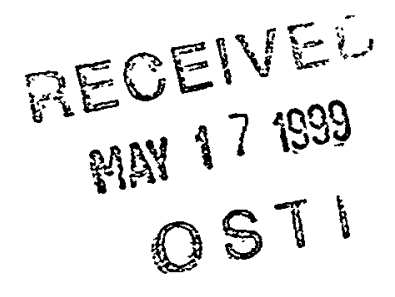

Neutronics Benchmarks for the Utilization of Mixed-Oxide Fuel: Joint U.S./Russian Progress Report for Fiscal Year 1997

Volume 4, Part 8-Neutron Poison Plates in Assemblies Containing Homogeneous Mixtures of Polystyrene-Moderated Plutonium and Uranium Oxides

Musa Yavuz

University of Texas 
This report was prepared as an account of work sponsored by an agency of the United States Government. Neither the United States Government nor any agency thereof, nor any of their employees, makes any warranty, express or implied, or assumes any legal liability or responsibility for the accuracy, completeness, or usefulness or any information, apparatus, product, or process disclosed, or represents that its use would not infringe privately owned rights. Reference herein to any specific commercial product, process, or service by trade name, trademark, manufacturer, or otherwise, does not necessarily constitute or imply its endorsement, recommendation, or favoring by the United States Government or any agency thereof. The views and opinions of authors expressed herein do not necessarily state or reflect those of the United States Government or any agency thereof. 


\section{DISCLAIMER}

Portions of this document may be illegible in electronic image products. Images are produced from the best available original document. 


\title{
NEUTRONICS BENCHMARKS FOR THE UTILIZATION OF MIXED-OXIDE FUEL: JOINT U.S./RUSSIAN PROGRESS REPORT FOR FISCAL YEAR 1997
}

\section{Volume 4, Part 8-Neutron Poison Plates in Assemblies Containing Homogeneous Mixtures of Polystyrene-Moderated Plutonium and Uranium Oxides}

\author{
Musa Yavuz
}

Date Published: May 1999

\author{
Report Prepared by \\ LOCKHEED MARTIN ENERGY RESEARCH CORP. \\ P.O. Box 2008 \\ Oak Ridge, Tennessee 37831-6363 \\ Under \\ Subcontract Number 85B99398V \\ Funded by \\ Office of Fissile Materials Disposition \\ United States Department of Energy \\ Prepared for \\ Computational Physics and Engineering Division \\ Oak Ridge National Laboratory \\ Oak Ridge, Tennessee 37831 \\ managed by \\ LOCKHEED MARTIN ENERGY RESEARCH CORP. \\ for the \\ U.S. DEPARTMENT OF ENERGY \\ under contract DE-96OR22464
}




\title{
NEUTRON POISON PLATES IN ASSEMBLIES CONTAINING HOMOGENEOUS MIXTURES OF POLYSTYRENE-MODERATED PLUTONIUM AND URANIUM OXIDES
}

\author{
Evaluator \\ Musa Yavuz \\ Department of Mechanical Engineering \\ The University of Texas at Austin \\ Internal Reviewer \\ Naeem M. Abdurrahman \\ Department of Mechanical Engineering \\ The University of Texas at Austin
}

External Reviewers

M. E. Dunn

R. T. Primm III

Oak Ridge National Laboratory 


\section{NEUTRON POISON PLATES IN ASSEMBLIES CONTAINING HOMOGENEOUS MIXTURES OF POLYSTYRENE-MODERATED PLUTONIUM AND URANIUM OXIDES ${ }^{a}$}

\section{Detailed Description}

\subsection{Overview of Experiment}

In the 1970s at the Battelle Pacific Northwest Laboratory (PNL), a series of critical experiments using a remotely operated Split-Table Machine was performed with homogeneous mixtures of $(\mathrm{Pu}-\mathrm{U}) \mathrm{O}_{2^{-}}$ polystyrene fuels in the form of square compacts having different heights. The experiments determined the critical geometric configurations of MOX fuel assemblies with and without neutron poison plates. With respect to $\mathrm{PuO}_{2}$ content and moderation $[\mathrm{H} /(\mathrm{Pu}+\mathrm{U})$ atomic] ratio $(\mathrm{MR})$, two different homogeneous ( $\mathrm{Pu}$ U) $\mathrm{O}_{2}$-polystyrene mixtures were considered: Mixture 1) $14.62 \mathrm{wt} \% \mathrm{PuO}_{2}$ with $30.6 \mathrm{MR}$, and Mixture 2) $30.3 \mathrm{wt} \% \mathrm{PuO}_{2}$ with $2.8 \mathrm{MR}$. In all mixtures, the uranium was depleted to about $0.151 \mathrm{wt} \% \mathrm{U}^{235}$. Assemblies contained copper, copper-cadmium or aluminum neutron poison plates having thicknesses up to $\sim 2.5 \mathrm{~cm}$.

This evaluation contains 22 experiments for Mixture 1, and 10 for Mixture 2 compacts. For Mixture 1, there are 10 configurations with copper plates, 6 with aluminum, and 5 with copper-cadmium. One experiment contained no poison plate. For Mixture 2 compacts, there are 3 configurations with copper, 3 with aluminum, and 3 with copper-cadmium poison plates. One experiment contained no poison plate.

\subsection{Description of Experimental Configuration}

A large glove box within a heavily shielded cell located at the PNL Critical Mass Laboratory (CML) was used for the experiments. The floor surface of CML is $1067 \mathrm{~cm}$ square, with $152-\mathrm{cm}$-thick side walls (except for a 91-cm-thick south wall) and a 61-cm-thick roof and floor [Smolen 1994]. A remotely operated Split-Table Machine (STM) shown in Figure 1 was used for performing the experiments. Each table half, one stationary and the other movable, had a steel frame. One of the table halves formed a surface $76-\mathrm{cm}$ wide and $61-\mathrm{cm}$ long, and the other formed a surface $76-\mathrm{cm}$ wide and $46-\mathrm{cm}$ long. The table surfaces were $51-\mathrm{cm}$ above the floor level. A $30-\mathrm{cm}$ thick aluminum honeycomb with an effective density of $0.037 \mathrm{~g} / \mathrm{cm}^{3}$ covered both table halves [Richey 1965]. The geometric dimensions of each fuel mixture, including unclad, clad and clad + void compacts are listed in Table 1. For each poison, thicknesses of plates and plate + void are given in Table 2 . The uncertainties in the compact dimensions are also shown in these tables [Bierman 1974].

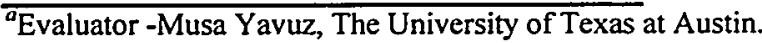
Internal Reviewer - Naeem M. Abdurrahman, The University of Texas at Austin External Reviewers - M. E. Dunn and R. Trenton Primm, III, Oak Ridge National Laboratory

Keywords: critical experiment, mixed oxide fuel, Plexiglas-reflected, plutonium, polystyrene-moderated, uranium 
Table 1. Fuel compact dimensions

\begin{tabular}{|c|c|c|c|}
\hline Compacts & Length (cm) & Width $(\mathrm{cm})$ & Height $(\mathrm{cm})$ \\
\hline \multicolumn{5}{|c|}{ Mixture 1 } \\
\hline Unclad & $5.090 \pm 0.005$ & $5.090 \pm 0.025$ & $\begin{array}{c}5.090 \pm 0.005 ; 3.400 \pm 0.044 ; \\
1.384 \pm 0.039\end{array}$ \\
\hline & & & $5.121 \pm 0.005 ; 3.431 \pm 0.044 ;$ \\
Clad & $5.121 \pm 0.005$ & $5.137 \pm 0.005$ & $0.015 \pm 039$ \\
\hline & & $5.130 \pm 0.010 ; 3.440 \pm 0.048 ;$ \\
Clad + void & $5.130 \pm 0.010$ & $5.190 \pm 0.025$ & $1.424 \pm 0.043$ \\
\hline \multicolumn{5}{|c|}{ Mixture 2 } \\
\hline Unclad & $5.090 \pm 0.005$ & $5.083 \pm 0.026$ & $5.090 \pm 0.005 ; 1.339 \pm 0.026$ \\
\hline Clad & $5.114 \pm 0.009$ & $5.170 \pm 0.026$ & $5.114 \pm 0.006 ; 1.363 \pm 0.026$ \\
\hline Clad + void & $5.118 \pm 0.015$ & $5.174 \pm 0.030$ & $5.118 \pm 0.015 ; 1.367 \pm 0.026$ \\
\hline
\end{tabular}

Table 2. Copper poison plates for Mixture 1 compacts

\begin{tabular}{|c|c|c|c|c|}
\hline & $\begin{array}{c}\text { Plate thickness } \\
(\mathrm{cm})\end{array}$ & $\begin{array}{c}\text { Plate }+ \text { Void } \\
\text { thickness } \\
(\mathrm{cm})\end{array}$ & $\begin{array}{c}\text { Reduced } \\
\text { density } \\
(\%)\end{array}$ & $\begin{array}{c}\text { Plate mass } \\
(\mathrm{kg})\end{array}$ \\
\hline 1 & $0.337 \pm 0.008$ & $0.40 \pm 0.06$ & 83.8 & $6.440 \pm 0.013$ \\
\hline 2 & $0.637 \pm 0.003$ & $0.71 \pm 0.07$ & 87.8 & $11.985 \pm 0.024$ \\
\hline 3 & $1.290 \pm 0.004$ & $1.35 \pm 0.06$ & 94.1 & $24.425 \pm 0.049$ \\
\hline 4 & $1.927 \pm 0.005$ & $2.02 \pm 0.09$ & 93.8 & $36.410 \pm 0.072$ \\
\hline 5 & $2.580 \pm 0.006$ & $2.70 \pm 0.10$ & 94.0 & $48.785 \pm 0.096$ \\
\hline 6 & $0.337 \pm 0.008$ & $0.40 \pm 0.06$ & 83.8 & $6.440 \pm 0.013$ \\
\hline 7 & $0.337 \pm 0.008$ & $0.37 \pm 0.03$ & 90.6 & $6.440 \pm 0.013$ \\
\hline 8 & $1.290 \pm 0.004$ & $1.33 \pm 0.04$ & 95.5 & $24.425 \pm 0.049$ \\
\hline 9 & $1.927 \pm 0.005$ & $1.98 \pm 0.05$ & 95.7 & $36.410 \pm 0.073$ \\
\hline 10 & $2.565 \pm 0.006$ & $2.68 \pm 0.06$ & 94.1 & $48.470 \pm 0.014$ \\
\hline 11 & $0.337 \pm 0.008$ & $0.37 \pm 0.03$ & 90.2 & $6.415 \pm 0.013$ \\
\hline 12 & $1.290 \pm 0.004$ & $1.33 \pm 0.03$ & 95.3 & $24.360 \pm 0.049$ \\
\hline 13 & $1.927 \pm 0.005$ & $1.98 \pm 0.05$ & 95.8 & $36.450 \pm 0.072$ \\
\hline 14 & $2.565 \pm 0.006$ & $2.68 \pm 0.06$ & 94.1 & $48.450 \pm 0.096$ \\
\hline
\end{tabular}

${ }^{a}$ Plate mass per plate and void volume relative to $8.913 \mathrm{~g} / \mathrm{cm}^{3}$.

Table 3. Aluminum poison plates for Mixture 1 compacts

\begin{tabular}{|c|c|c|c|c|}
\hline & $\begin{array}{c}\text { Plate thickness } \\
(\mathrm{cm})\end{array}$ & $\begin{array}{c}\text { Plate }+ \text { Void } \\
\text { thickness } \\
(\mathrm{cm})\end{array}$ & $\begin{array}{c}\text { Reduced } \\
\text { density } \\
(\%)\end{array}$ & $\begin{array}{c}\text { Plate mass } \\
(\mathrm{kg})\end{array}$ \\
\hline 1 & $0.316 \pm 0.001$ & $0.40 \pm 0.08$ & 77.1 & $1.790 \pm 0.025$ \\
\hline 2 & $0.645 \pm 0.002$ & $0.73 \pm 0.08$ & 86.5 & $3.665 \pm 0.012$ \\
\hline 3 & $1.983 \pm 0.004$ & $2.06 \pm 0.07$ & 94.2 & $11.270 \pm 0.049$ \\
\hline 4 & $2.676 \pm 0.002$ & $2.75 \pm 0.07$ & 95.5 & $15.250 \pm 0.034$ \\
\hline 5 & $0.316 \pm 0.001$ & $0.34 \pm 0.02$ & 90.7 & $1.790 \pm 0.025$ \\
\hline 6 & $2.628 \pm 0.004$ & $2.68 \pm 0.05$ & 96.0 & $14.940 \pm 0.056$ \\
\hline 7 & $0.317 \pm 0.002$ & $0.34 \pm 0.02$ & 90.7 & $1.790 \pm 0.025$ \\
\hline 8 & $2.629 \pm 0.013$ & $2.69 \pm 0.05$ & 95.8 & $14.965 \pm 0.031$ \\
\hline
\end{tabular}

${ }^{a}$ Plate mass per plate and void volume relative to $2.692 \mathrm{~g} / \mathrm{cm}^{3}$. 
Table 4. Copper-Cadmium poison plates for Mixture 1 compacts

\begin{tabular}{|c|c|c|c|c|}
\hline Plate number & $\begin{array}{c}\text { Plate thickness } \\
(\mathrm{cm})\end{array}$ & $\begin{array}{c}\text { Plate +Void } \\
\text { thickness } \\
(\mathrm{cm})\end{array}$ & $\begin{array}{c}\text { Reduced } \\
\text { density } \\
(\%)\end{array}$ & $\begin{array}{c}\text { Plate mass } \\
(\mathrm{kg})\end{array}$ \\
\hline 1 & $0.368 \pm 0.005$ & $0.43 \pm 0.06$ & 83.6 & $6.905 \pm 0.014$ \\
\hline 2 & $2.160 \pm 0.006$ & $2.30 \pm 0.10$ & 91.9 & $40.635 \pm 0.081$ \\
\hline 3 & $0.368 \pm 0.005$ & $0.43 \pm 0.06$ & 83.6 & $6.905 \pm 0.014$ \\
\hline 4 & $0.368 \pm 0.005$ & $0.43 \pm 0.06$ & 86.6 & $6.905 \pm 0.014$ \\
\hline 5 & $0.368 \pm 0.005$ & $0.41 \pm 0.04$ & 87.6 & $6.905 \pm 0.014$ \\
\hline 6 & $0.354 \pm 0.005$ & $0.39 \pm 0.03$ & 89.2 & $6.685 \pm 0.013$ \\
\hline
\end{tabular}

${ }^{a}$ Plate mass per plate and void volume relative to $8.910 \mathrm{~g} / \mathrm{cm}^{3}$.

Table 5. Poison plates for Mixture 2 compacts

\begin{tabular}{|c|c|c|c|c|}
\hline Plate number & $\begin{array}{c}\text { Plate thickness } \\
(\mathrm{cm})\end{array}$ & $\begin{array}{c}\text { Plate +Void } \\
\text { thickness } \\
(\mathrm{cm})\end{array}$ & $\begin{array}{c}\text { Reduced } \\
\text { density } \\
(\%)\end{array}$ & $\begin{array}{c}\text { Plate mass } \\
(\mathrm{kg})\end{array}$ \\
\hline \multicolumn{5}{|c|}{ Copper } \\
\hline 1 & $0.337 \pm 0.008$ & $0.41 \pm 0.07$ & 82.2 & $6.440 \pm 0.013$ \\
\hline 2 & $0.974 \pm 0.008$ & $1.02 \pm 0.07$ & 94.5 & $18.425 \pm 0.037$ \\
\hline 3 & $1.964 \pm 0.012$ & $2.06 \pm 0.08$ & 95.0 & $37.280 \pm 0.075$ \\
\hline 1 & $0.316 \pm 0.001$ & $0.39 \pm 0.07$ & 79.5 & $1.790 \pm 0.025$ \\
\hline 2 & $0.961 \pm 0.002$ & $1.01 \pm 0.05$ & 93.5 & $5.455 \pm 0.044$ \\
\hline 3 & $1.971 \pm 0.005$ & $2.04 \pm 0.08$ & 95.0 & $11.185 \pm 0.083$ \\
\hline \multicolumn{5}{|c|}{ Copper-Cadmium plates } \\
\hline 1 & $0.386 \pm 0.005$ & $0.46 \pm 0.07$ & 78.5 & $6.905 \pm 0.014$ \\
\hline 2 & $1.085 \pm 0.005$ & $1.18 \pm 0.09$ & 90.5 & $20.419 \pm 0.040$ \\
\hline 3 & $2.160 \pm 0.006$ & $2.28 \pm 0.09$ & 93.2 & $40.635 \pm 0.081$ \\
\hline
\end{tabular}

${ }^{a}$ Relative to respective densities reported in Tables 2-4.

Arrays of the same fuel mixture compacts with and without poison plates were stacked together on the STM. The assemblies had a base of $9 \leftarrow 9$ fuel compacts having different heights. The poison plates were positioned horizontally in the assemblies. The plate cross-section dimensions were the same as the $9 \leftrightarrow 9$ assembly dimensions. The thicknesses of the plates are given in Tables 2-5. To approach criticality, the smaller size compacts were used by incrementally loading them onto the top face of each assembly in a symmetrical manner with respect to neutron flux. In all assembly configurations, a $15-\mathrm{cm}$-thick methacrylate plastic (Plexiglas) reflector was used.

\subsection{Description of Material Data}

Two-different homogeneous ( $\mathrm{Pu}-\mathrm{U}) \mathrm{O}_{2}$-polystyrene mixtures with respect to $\mathrm{PuO}_{2}$ content and $\mathrm{MR}$ were considered. Mixture 1 contained $14.62 \mathrm{wt} \% \mathrm{PuO}_{2}$ with $30.6 \mathrm{MR}$, and Mixture 2 contained $30.3 \mathrm{wt} \% \mathrm{PuO}_{2}$ with $2.8 \mathrm{MR}$. The number densities of these mixture compacts including clad and Plexiglas reflector are shown in Table 6. The uranium was depleted to about $0.151 \mathrm{wt} \% \mathrm{U}^{235}$ in all mixtures. For the poison plates, three compositions under the names of copper, aluminum, copper-cadmium were considered; the material contents are listed in Table 7. Additional material properties of Mixtures 1 and 2 compacts, and the particle size distribution for fuel mixtures are displayed in Tables 8 and 9, respectively. 
Table 6. Composition of fuel mixtures and reflector material

\begin{tabular}{|l|l|l|l|l|}
\hline \multirow{2}{*}{ Nuclide } & \multicolumn{4}{|c|}{ Atomic density $\left(\mathrm{E}+24^{a}\right.$ atom $\left./ \mathrm{cm}^{3}\right)$} \\
\hline & Mixture 1 & Mixture 2 & Clad & Reflector \\
\hline $\mathrm{Am}^{241}$ & $4.036 \mathrm{E}-07^{b}$ & $1.017 \mathrm{E}-05^{c}$ & & \\
\hline $\mathrm{Pu}^{238}$ & 0.0 & $2.288 \mathrm{E}-06$ & & \\
\hline $\mathrm{Pu}^{239}$ & $1.954 \mathrm{E}-04$ & $2.186 \mathrm{E}-03$ & & \\
\hline $\mathrm{Pu}^{240}$ & $1.702 \mathrm{E}-05$ & $2.927 \mathrm{E}-04$ & & \\
\hline $\mathrm{Pu}^{241}$ & $1.211 \mathrm{E}-06$ & $5.875 \mathrm{E}-05$ & & \\
\hline $\mathrm{Pu}^{242}$ & 0.0 & $6.751 \mathrm{E}-06$ & & \\
\hline $\mathrm{U}^{235}$ & $1.904 \mathrm{E}-06$ & $9.269 \mathrm{E}-06$ & & \\
\hline $\mathrm{U}^{238}$ & $1.252 \mathrm{E}-03$ & $6.162 \mathrm{E}-03$ & & $1.428 \mathrm{E}-02$ \\
\hline $\mathrm{O}$ & $3.023 \mathrm{E}-03$ & $1.864 \mathrm{E}-02$ & & $5.712 \mathrm{E}-02$ \\
\hline $\mathrm{H}$ & $4.489 \mathrm{E}-02$ & $2.432 \mathrm{E}-02$ & $4.489 \mathrm{E}-02$ & $3.570 \mathrm{E}-02$ \\
\hline $\mathrm{C}$ & $4.412 \mathrm{E}-02$ & $2.660 \mathrm{E}-02$ & $3.110 \mathrm{E}-02$ & \\
\hline $\mathrm{Cl}$ & & & $7.240 \mathrm{E}-03$ & \\
\hline
\end{tabular}

${ }^{a}$ Read E+24 as $10^{24}$.

${ }^{b}$ Isotopic analysis made on May 28, 1970. Experiments performed May 1973.

'Isotopic analysis made on Dec. 2, 1971. Experiments performed June 1973.

Table 7. Composition of neutron poison plates

\begin{tabular}{|c|c|c|c|}
\hline Element & $\begin{array}{c}\text { Copper } \\
\left(8.913 \mathrm{~g} / \mathrm{cm}^{3}\right) \\
(\mathrm{wt} \%)\end{array}$ & $\begin{array}{c}\text { Copper- } \\
\text { Cadmium } \\
\left(8.910 \mathrm{~g} / \mathrm{cm}^{3}\right) \\
(\mathrm{wt} \%)\end{array}$ & $\begin{array}{c}\text { Aluminum } \\
\left(2.692 \mathrm{~g} / \mathrm{cm}^{3}\right) \\
(\mathrm{wt} \%)\end{array}$ \\
\hline $\mathrm{Cu}$ & 99.960 & 98.685 & 0.14 \\
\hline $\mathrm{Cd}$ & - & 0.989 & - \\
\hline $\mathrm{Al}$ & - & - & 97.98 \\
\hline $\mathrm{Zn}$ & 0.001 & 0.007 & 0.25 \\
\hline $\mathrm{Sn}$ & - & 0.250 & - \\
\hline $\mathrm{Ni}$ & - & 0.010 & - \\
\hline $\mathrm{Fe}$ & 0.003 & 0.020 & 0.70 \\
\hline $\mathrm{Cr}$ & - & - & 0.15 \\
\hline $\mathrm{Mn}$ & - & 0.009 & 0.15 \\
\hline $\mathrm{Mg}$ & 0.001 & - & 0.08 \\
\hline $\mathrm{Ti}$ & - & - & 0.15 \\
\hline $\mathrm{Si}$ & 0.001 & 0.004 & - \\
\hline $\mathrm{O}$ & 0.030 & 0.019 & - \\
\hline $\mathrm{C}$ & 0.004 & 0.002 & - \\
\hline $\mathrm{B}$ & - & 0.005 & - \\
\hline & & & - \\
\hline
\end{tabular}

Table 8. Material densities of plutonium, uranium, and clad

\begin{tabular}{|c|c|c|}
\hline Material density $\left(\mathrm{g} / \mathrm{cm}^{3}\right)$ & Mixture 1 & Mixture 2 \\
\hline Cladding & 1.12 & 1.12 \\
\hline Uranium & $0.495 \pm 0.005$ & $2.438 \pm 0.023$ \\
\hline Plutonium & $0.085 \pm 0.001$ & $1.012 \pm 0.010$ \\
\hline Fuel compact density & $1.615 \pm 0.017$ & $4.520 \pm 0.043$ \\
\hline Clad mass per compact $(\mathrm{g})$ & 3.175 & 2.432 \\
\hline
\end{tabular}


Table 9. Particle size distribution in $\mathrm{PuO}_{2}-\mathrm{UO}_{2}$ polystyrene fuels

\begin{tabular}{|c|c|c|c|}
\hline \multirow{2}{*}{ Distribution (\%) } & \multicolumn{3}{|c|}{ Particle diameter $(\mu \mathrm{m})$} \\
\cline { 2 - 4 } & $\mathrm{PuO}_{2}$ & $\mathrm{UO}_{2}$ & Polystyrene \\
\hline 95 & $<2$ & $<40$ & $<225$ \\
\hline 50 & $<8$ & $<9$ & $<150$ \\
\hline 5 & $<2$ & $<2$ & $<50$ \\
\hline
\end{tabular}

\subsection{Supplemental Experimental Measurements}

No additional experimental data were found.

\section{Evaluation of Experimental Data}

Material densities for fuel compacts, cladding and stacking void dimensions were well documented.

The geometric units of fuel compacts and poison plates were reported both in inches and the SI units in the text and in some tables. However, the SI units were used in this evaluation to be consistent with the units of critical experiment configurations.

The exact configurations of experiments including the number of compacts used in loading the assemblies were not provided. Instead, experimental corrections in critical heights were given.

For each type of fuel, the effects of the cladding and stacking voids were experimentally determined. This is not explained in detail in [Bierman 1974]. Instead, earlier studies were referenced. In those studies [Bierman 1973], the experimentally corrected dimensions of solid fuels were determined by extrapolation. In other words, the critical heights for a particular mixture were plotted as a function of layers of cladding material. The critical height data points were extrapolated to zero cladding to determine the critical height of solid fuels only.

The total mass and thickness of copper, copper-cadmium, or aluminum poison plates in some of the assemblies were the sum of several thinner plates stacked on top of one another to achieve the plate thicknesses that are given in Tables 2-5. However, the number of thinner plates summed to obtain the combined poison plate thicknesses were not given.

For Mixture 1, it was reported that the fuel regions can be expressed as homogeneous regions of $\mathrm{PuO}_{2}+\mathrm{UO}_{2}+$ polystyrene fuel only by reducing the amount of fuel in each assembly $3.92 \%$. In addition, the reduced density for homogenization of poison plate mass and void volume was reported for simplifying the calculational model. However, in this evaluation, no simplifications were considered in modeling the experiments.

\section{Benchmark Specifications}

\subsection{Description of Model}

The benchmark models consisted of $9 \leftarrow 9$ arrays of square compacts each containing the same mixture material. Arrays of compacts with and without poison plates were stacked together on the STM. Each compact contained the cladding material with specified heights and stacking voids described in Section 1.2. The geometric heights of the compacts were variable while the width and the length of the compacts were the same in loading the critical assemblies. The poison plates were positioned horizontally in the 
assemblies. All assemblies contained $9 \leftrightarrow 9$ base fuel compacts and are fully reflected by 15 -cm-thick Plexiglas.

\subsection{Dimensions}

The critical dimensions and configurations for Mixtures 1 and 2 experiments are given in Tables 10-13. These tables can be used to obtain a more simplified geometry description of each assembly. The number of fuel layers above, below; and between (when applicable) the poison plates are given. Fractional layers should be treated as full layers of thinner fuel compacts having a thickness equal to the fractional layer times the full-sized compact. Table 14 contains critical dimensions, in terms of number of compacts, for the experiments free from poison plates.

In Tables 10-12, the first column contains the case number. The second column gives the number of 3.4$\mathrm{cm}$-thick fuel compact layers below the poison plate. The third column contains the poison plate number whose geometric dimensions are given in Section 1.2. The fourth (and sixth) columns show the number of fuel layers having 5.09- and 1.384-cm-thick compacts above (and below) the poison plate. The fifth column describes the second poison plate number (if any). The last column gives the effective number of fuel layer compacts expressed as 5.09 -cm-thick fuel compacts.

In Table 13 for Mixture 2 experiments, the assemblies contained a single poison plate layer. The first column in Table 13 contains the experiment identification number. The second column contains the number of $5.09-\mathrm{cm}$-thick fuel compact layers below poison plate. The third column gives the poison plate number. The fourth column shows the number of fuel layers having 5.09- and 1.339-cm-thick compacts above the poison plate. The last column gives the total number of fuel layers in terms of $5.09-\mathrm{cm}$-thick fuel compacts. 
Table 10. Critical configurations for Mixture 1 compacts with copper neutron poison plates

\begin{tabular}{|c|c|c|c|c|c|c|c|c|}
\hline \multirow[t]{2}{*}{ Case } & \multirow{2}{*}{$\begin{array}{c}\begin{array}{c}\text { Fuel layers below } \\
\text { poison plate }\end{array} \\
3.4 \mathrm{~cm}\end{array}$} & \multirow[t]{2}{*}{$\begin{array}{c}\text { Poison } \\
\text { plate } \\
\text { number }\end{array}$} & \multicolumn{2}{|c|}{$\begin{array}{c}\text { Fuel layers above } \\
\text { poison plate }\end{array}$} & \multirow[t]{2}{*}{$\begin{array}{c}\text { Poison } \\
\text { plate } \\
\text { number }\end{array}$} & \multicolumn{2}{|c|}{$\begin{array}{c}\text { Fuel layers above } \\
\text { poison plate }\end{array}$} & \multirow{2}{*}{$\begin{array}{c}\begin{array}{c}\text { Total layers } \\
\text { of fuel }\end{array} \\
5.09 \mathrm{~cm}\end{array}$} \\
\hline & & & $5.09 \mathrm{~cm}$ & $1.384 \mathrm{~cm}$ & & $5.09 \mathrm{~cm}$ & $1.384 \mathrm{~cm}$ & \\
\hline 1 & 3 & 1 & 2 & 2.415 & - & - & - & $4.661 \pm 0.005$ \\
\hline 2 & 3 & 2 & 2 & 3.110 & - & - & - & $4.850 \pm 0.004$ \\
\hline 3 & 3 & 3 & 3 & 0.463 & - & - & - & $5.130 \pm 0.010$ \\
\hline 4 & 3 & 4 & 3 & 1.136 & - & - & - & $5.313 \pm 0.005$ \\
\hline 5 & 3 & 5 & 3 & 1.746 & - & - & - & $5.479 \pm 0.001$ \\
\hline 6 & $a$ & 6 & 1 & 2.349 & - & - & - & $4.643 \pm 0.005$ \\
\hline 7 & 3 & 7 & 1 & 0 & 11 & 1 & 3.603 & $4.984 \pm 0.005$ \\
\hline 8 & 3 & 8 & 1 & 0 & 12 & 2 & 3.584 & $5.979 \pm 0.005$ \\
\hline 9 & 3 & 9 & 1 & 0 & 13 & 3 & 1.129 & $6.311 \pm 0.003$ \\
\hline 10 & 3 & 10 & 1 & 0 & 14 & 3 & 2.092 & $6.573 \pm 0.003$ \\
\hline
\end{tabular}

${ }^{a}$ Three layers of $3.4 \mathrm{~cm}$ plus one layer of $5.09-\mathrm{cm}$-thick fuel compacts below poison plate.

${ }^{b}$ Total layers of fuel compacts expressed as equivalent $5.09-\mathrm{cm}$-thick compacts. Multiply by 0.9608 to correct for the reactivity effects of stacking voids and the cladding. 
Table 11. Critical configurations for Mixture 1 compacts with aluminum neutron poison plates

\begin{tabular}{|c|c|c|c|c|c|c|c|c|}
\hline \multirow[t]{2}{*}{ Case } & \multirow{2}{*}{$\begin{array}{c}\begin{array}{c}\text { Fuel layers below } \\
\text { poison plate }\end{array} \\
3.4 \mathrm{~cm} \\
\end{array}$} & \multirow[t]{2}{*}{$\begin{array}{c}\text { Poison } \\
\text { plate } \\
\text { number }\end{array}$} & \multicolumn{2}{|c|}{$\begin{array}{c}\text { Fuel layers above } \\
\text { poison plate }\end{array}$} & \multirow[t]{2}{*}{$\begin{array}{c}\text { Poison } \\
\text { plate } \\
\text { number }\end{array}$} & \multicolumn{2}{|c|}{$\begin{array}{c}\text { Fuel layers above } \\
\text { poison plate }\end{array}$} & \multirow{2}{*}{$\begin{array}{c}\begin{array}{c}\text { Total } \\
\text { layers of } \\
\text { fuel }^{a}\end{array} \\
5.09 \mathrm{~cm} \\
\end{array}$} \\
\hline & & & $5.09 \mathrm{~cm}$ & $1.384 \mathrm{~cm}$ & & $5.09 \mathrm{~cm}$ & $1.384 \mathrm{~cm}$ & \\
\hline 1 & 3 & 1 & 2 & 1.548 & - & - & - & $4.425 \pm 0.003$ \\
\hline 2 & 3 & 2 & 2 & 1.739 & - & - & - & $4.477 \pm 0.007$ \\
\hline 3 & 3 & 3 & 2 & 2.713 & 二 & - & - & $4.742 \pm 0.004$ \\
\hline 4 & 3 & 4 & 2 & 3.158 & - & - & - & $4.863 \pm 0.003$ \\
\hline 5 & 3 & 5 & 1 & 0 & 7 & 1 & 1.812 & $4.497 \pm 0.002$ \\
\hline 6 & 3 & 6 & 1 & 0 & 8 & 2 & 1.151 & $5.317 \pm 0.003$ \\
\hline
\end{tabular}

${ }^{a}$ Total layers of fuel compacts expressed as equivalent 5.09 -cm-thick compacts. Multiply by 0.9608 to correct for the reactivity effects of stacking voids and the cladding.

Table 12. Critical configurations for Mixture 1 compacts with copper-cadmium neutron poison plates

\begin{tabular}{|c|c|c|c|c|c|c|c|c|}
\hline \multirow[t]{2}{*}{ Case } & \multirow{2}{*}{$\begin{array}{c}\begin{array}{c}\text { Fuel layers below } \\
\text { poison plate }\end{array} \\
3.4 \mathrm{~cm} \\
\end{array}$} & \multirow[t]{2}{*}{$\begin{array}{l}\text { Poison } \\
\text { plate } \\
\text { number }\end{array}$} & \multicolumn{2}{|c|}{$\begin{array}{c}\text { Fuel layers above } \\
\text { poison plate }\end{array}$} & \multirow[t]{2}{*}{$\begin{array}{c}\text { Poison } \\
\text { plate } \\
\text { number }\end{array}$} & \multicolumn{2}{|c|}{$\begin{array}{c}\text { Fuel layers above } \\
\text { poison plate }\end{array}$} & \multirow{2}{*}{$\begin{array}{c}\text { Total } \\
\begin{array}{c}\text { layers of } \\
\text { fuel }^{\circ}\end{array} \\
5.09 \mathrm{~cm} \\
\end{array}$} \\
\hline & & & $5.09 \mathrm{~cm}$ & $1.384 \mathrm{~cm}$ & & $5.09 \mathrm{~cm}$ & $1.384 \mathrm{~cm}$ & \\
\hline 1 & 3 & 1 & 3 & 0.757 & 二 & - & - & $5.210 \pm 0.003$ \\
\hline 2 & 3 & 2 & 3 & 2.698 & - & - & $=$ & $5.738 \pm 0.006$ \\
\hline 3 & $a$ & 3 & 2 & 0.952 & - & - & - & $5.263 \pm 0.003$ \\
\hline 4 & $b$ & 4 & 0 & 3.463 & - & - & - & $4.946 \pm 0.002$ \\
\hline 5 & 3 & 5 & 1 & 0 & 6 & 3 & 0.331 & $6.094 \pm 0.022$ \\
\hline
\end{tabular}

${ }^{a}$ Three layers of $3.4 \mathrm{~cm}$ plus one layer of $5.09-\mathrm{cm}$-thick fuel compacts below poison plate.

${ }^{b}$ Three layers of $3.4 \mathrm{~cm}$ plus two layers of $5.09-\mathrm{cm}$-thick fuel compacts below poison plate.

${ }^{c}$ Total layers of fuel compacts expressed as equivalent $5.09-\mathrm{cm}$-thick compacts. Multiply by 0.9608 to correct for the reactivity effects of stacking voids and the cladding. 
Table 13. Critical configurations for Mixture 2 compacts with poison plates

\begin{tabular}{|c|c|c|c|c|c|}
\hline \multirow[t]{2}{*}{ Case } & \multirow{2}{*}{$\begin{array}{c}\text { Fuel layers below } \\
\text { poison plate }\end{array}$} & \multirow[t]{2}{*}{$\begin{array}{l}\text { Poison } \\
\text { plate } \\
\text { number }\end{array}$} & \multicolumn{2}{|c|}{$\begin{array}{c}\text { Fuel layers above } \\
\text { poison plate }\end{array}$} & \multirow{2}{*}{$\begin{array}{c}\text { Total } \\
\text { layers of } \\
\text { fuel }^{a}\end{array}$} \\
\hline & & & $5.09 \mathrm{~cm}$ & $1.339 \mathrm{~cm}$ & \\
\hline \multicolumn{6}{|c|}{ Copper poison plates } \\
\hline 1 & 3 & 1 & 2 & 0.502 & $5.119 \pm 0.010$ \\
\hline 2 & 3 & 2 & 2 & 1.321 & $5.313 \pm 0.004$ \\
\hline 3 & 3 & 3 & 2 & 2.536 & $5.601 \pm 0.013$ \\
\hline \multicolumn{6}{|c|}{ Aluminum poison plates } \\
\hline 1 & 3 & 1 & 2 & 0.342 & $5.081 \pm 0.012$ \\
\hline 2 & 3 & 2 & 2 & 0.873 & $5.207 \pm 0.016$ \\
\hline 3 & 3 & 3 & 2 & 1.688 & $5.400 \pm 0.004$ \\
\hline \multicolumn{6}{|c|}{ Copper-Cadmium poison plates } \\
\hline 1 & 3 & 1 & 2 & 0.738 & $5.175 \pm 0.010$ \\
\hline 2 & 3 & 2 & 2 & 1.827 & $5.433 \pm 0.003$ \\
\hline 3 & 3 & 3 & 2 & 3.468 & $5.822 \pm 0.007$ \\
\hline
\end{tabular}

${ }^{a}$ Total layers of fuel compacts expressed as equivalent 5.09 -cm-thick compacts. Multiply by 0.9608 to correct for the reactivity effects of stacking voids and the cladding.

Table 14. Critical configurations with no poison plate

\begin{tabular}{|c|c|c|c|c|}
\hline Case & \multicolumn{3}{|c|}{ Fuel layers } & Total layers of fuel ${ }^{a}$ \\
\hline \multicolumn{5}{|c|}{ Mixture 1} \\
\hline & $3.4 \mathrm{~cm}$ & $5.09 \mathrm{~cm}$ & $1.384 \mathrm{~cm}$ & $5.09 \mathrm{~cm}$ \\
\hline 1 & 3 & 2 & 1.276 & $4.351 \pm 0.004$ \\
\hline \multicolumn{5}{|c|}{ Mixture 2} \\
\hline & $3.4 \mathrm{~cm}$ & $5.09 \mathrm{~cm}$ & $1.339 \mathrm{~cm}$ & $5.09 \mathrm{~cm}$ \\
\hline 1 & - & 4 & 4.207 & $4.997 \pm 0.013$ \\
\hline
\end{tabular}

${ }^{a}$ Total layers of fuel compacts expressed as equivalent 5.09 -cm-thick compacts. Multiply by 0.9608 to correct for the reactivity effects of stacking voids and the cladding.

\subsection{Material Data}

The number densities of Mixtures 1 and 2 are given in Table 6, and poison plate composition data are provided in Table 7.

\subsection{Temperature Data}

No temperature data was provided.

\section{Results of Sample Calculations}

The sample $k_{\text {eff }}$ calculations were performed using MCNP4A with continuous energy cross sections based on the ENDF/B-VI library. Polyethylene thermal cross sections (poly.01t card) are used for both fuel mixtures and Plexiglas. In calculations, 4000 particle histories, 200 active and 25 skipped generations were used. However, additional particle histories were run if $k_{\text {eff }}$ had not attained a constant level after 800000 
active particle histories. In Tables $15-17$, the calculated $k_{\mathrm{eff}}$ values are listed. Sample input listings are given in Section 6.

Table 15. MCNP $\mathrm{k}_{\text {eff }}$ for Mixture 1 experiments in Tables $10-12$

\begin{tabular}{|c|c|c|c|}
\hline Case & Copper poison plate & Aluminum poison plate & $\begin{array}{c}\text { Copper-Cadmium } \\
\text { poison plate }\end{array}$ \\
\hline 1 & $1.01158 \pm 0.00098$ & $1.00989 \pm 0.00093$ & $1.01166 \pm 0.00092$ \\
\hline 2 & $1.00840 \pm 0.00099$ & $1.01159 \pm 0.00094$ & $1.00912 \pm 0.00095$ \\
\hline 3 & $1.01164 \pm 0.00093$ & $1.01125 \pm 0.00099$ & $1.01324 \pm 0.00104$ \\
\hline 4 & $1.00928 \pm 0.00094$ & $1.00969 \pm 0.00098$ & $1.01093 \pm 0.00094$ \\
\hline 5 & $1.01030 \pm 0.00101$ & $1.01231 \pm 0.00094$ & $1.01134 \pm 0.00064$ \\
\hline 6 & $1.01206 \pm 0.00092$ & $1.00770 \pm 0.00099$ & \\
\hline 7 & $1.01225 \pm 0.00096$ & & \\
\hline 8 & $1.01162 \pm 0.00101$ & & \\
\hline 9 & $1.00745 \pm 0.00086$ & & \\
\hline 10 & $1.00744 \pm 0.00098$ & & \\
\hline
\end{tabular}

Table 16. MCNP $k_{\text {eff }}$ for Mixture 2 experiments in Table 13

\begin{tabular}{|c|c|c|c|}
\hline Case & Copper poison plate & Aluminum poison plate & $\begin{array}{c}\text { Copper-Cadmium } \\
\text { poison plate }\end{array}$ \\
\hline 1 & $0.99808 \pm 0.00081$ & $0.99993 \pm 0.00096$ & $0.99889 \pm 0.00094$ \\
\hline 2 & $0.99912 \pm 0.00081$ & $1.00060 \pm 0.00081$ & $0.99856 \pm 0.00084$ \\
\hline 3 & $0.99953 \pm 0.00087$ & $1.00021 \pm 0.00082$ & $1.00020 \pm 0.00086$ \\
\hline
\end{tabular}

Table 17. MCNP $k_{\text {eff }}$ for experiments free from poison plate

\begin{tabular}{|c|c|c|}
\hline Case & Mixture 1 & Mixture 2 \\
\hline 1 & $1.01160 \pm 0.00093$ & $1.00234 \pm 0.00087$ \\
\hline
\end{tabular}

Acknowledgments: John White, Oak Ridge National Laboratory, and Rollin Harding of Brookhaven National Laboratory provided the "zinc" library based on the ENDL92 evaluation.

\section{References}

Bierman 1973. S. R. Bierman, and E. D. Clayton, "Critical with Homogeneous Mixtures of Plutonium and Uranium Oxides Containing 8, 15, and 30 wt\% Plutonium," Nucl. Sci. Eng., 50, 115-126 (1973).

Bierman 1974. S. R. Bierman, and E. D. Clayton, "Critical Experiments to Measure the Neutron Poisoning Effects of Copper and Copper-Cadmium Plates," Nucl. Sci. Eng., 55, 58-66 (1974).

Richey 1965. C. R. Richey, J. D. White, E. D. Clayton and R. C. Lloyd, "Criticality of Homogeneous Plutonium Oxide-Plastic Compacts at H:Pu=15," Nucl. Sci. Eng., 23, 150-158 (1965).

Smolen 1994. G. R. Smolen, R. C. Lloyd, and H. Funabashi, "Critical Data and Validation Studies of Plutonium-Uranium Nitrate Solutions in Cylindrical and Slab Geometry, Nuclear Technology, 107, 304 (1994). 


\subsubsection{Sample MCNP Input Listings}

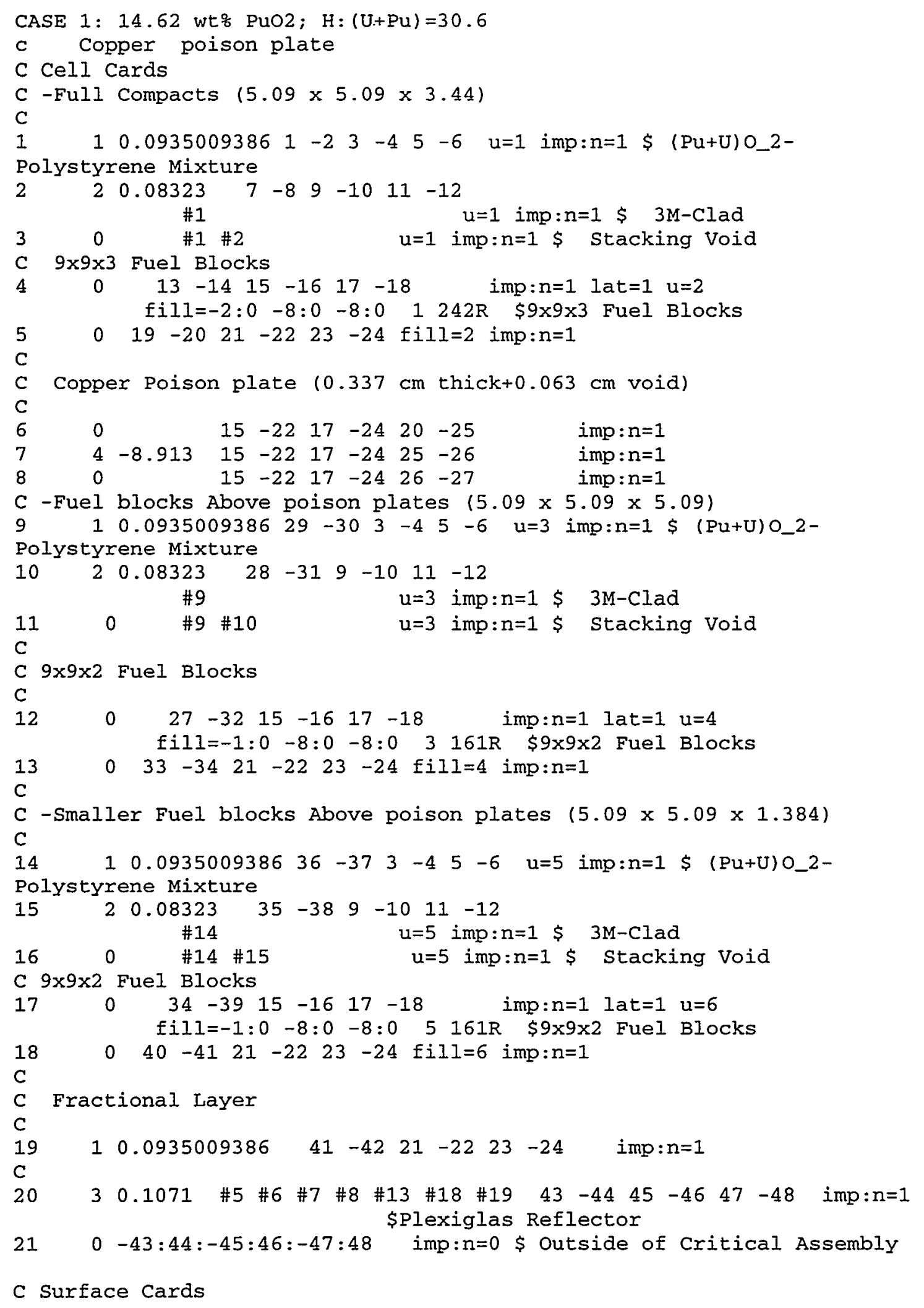




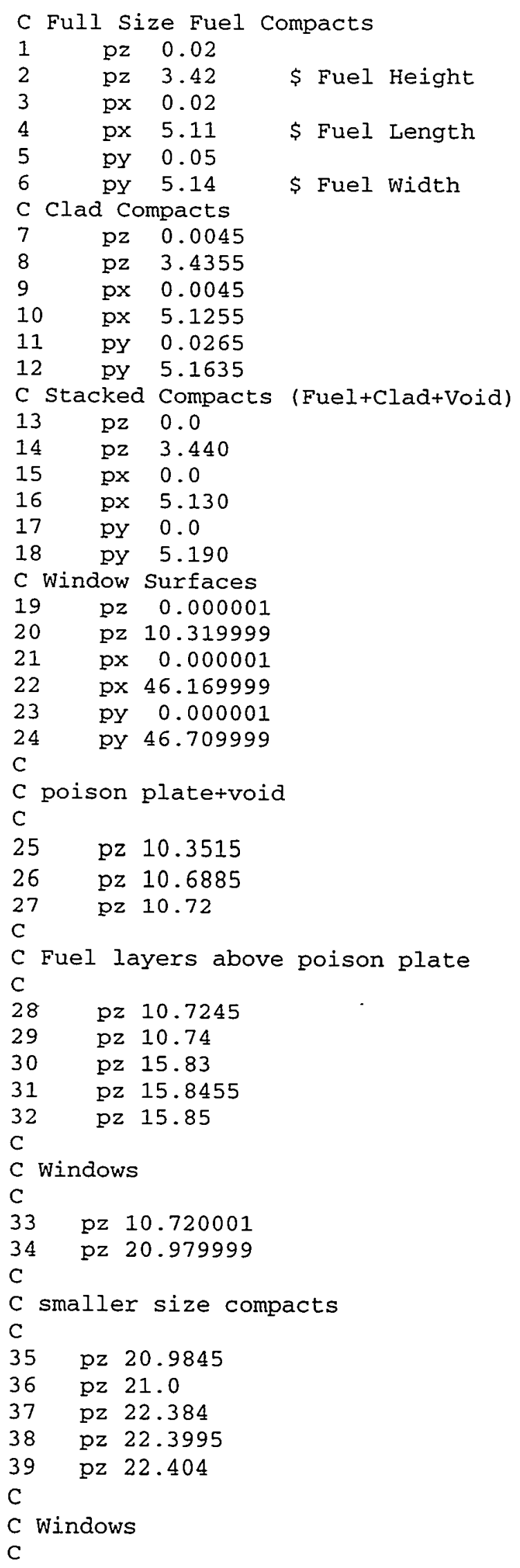




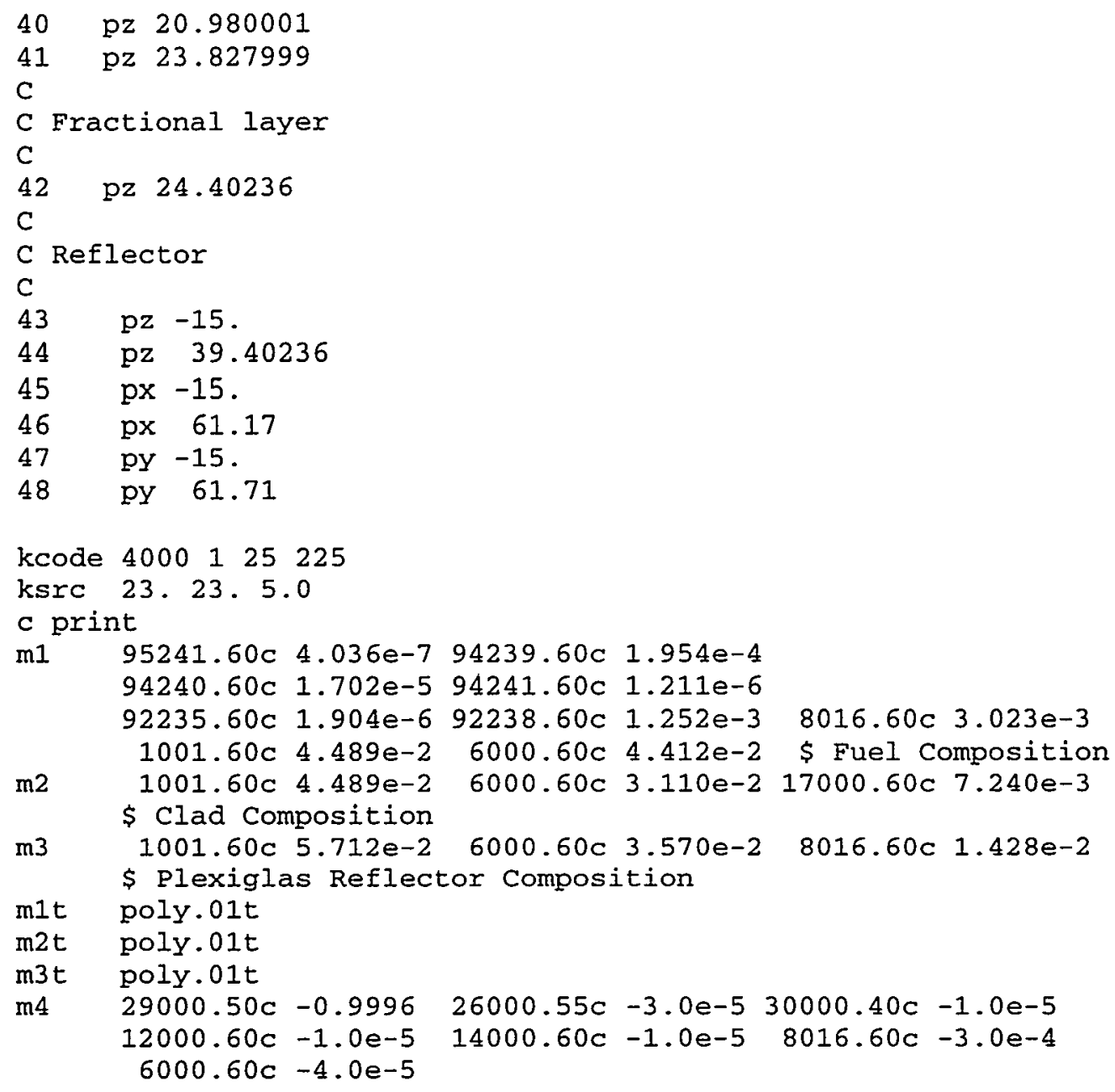


CASE 1 (TAble 11): 14.62 wt: PuO2; H: $(\mathrm{U}+\mathrm{Pu})=30.6$

C

C Cell Cards

Aluminum poison plate

C -Full Compacts $(5.09 \times 5.09 \times 3.44)$

C

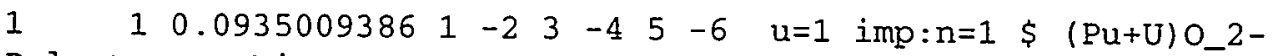
Polystyrene Mixture

$\begin{array}{lllllllll}2 & 2 & 0.08323 & 7 & -8 & 9 & -10 & 11 & -12\end{array}$

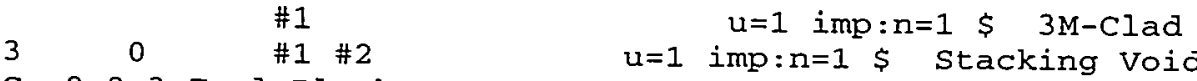

$9 \times 9 \times 3$ Fuel Blocks

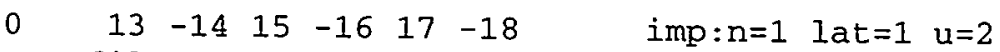

fill $=-2: 0-8: 0-8: 0 \quad 1242 \mathrm{R} \quad \$ 9 \times 9 \times 3$ Fuel Blocks

$5 \quad \begin{array}{lllllllll}5 & 19 & -20 & 21 & -22 & 23 & -24 & \text { fill=2 } & \text { imp: } n=1\end{array}$

$\mathrm{C}$

C

Copper Poison plate $(0.316 \mathrm{~cm}$ thick $+0.084 \mathrm{~cm}$ void) 


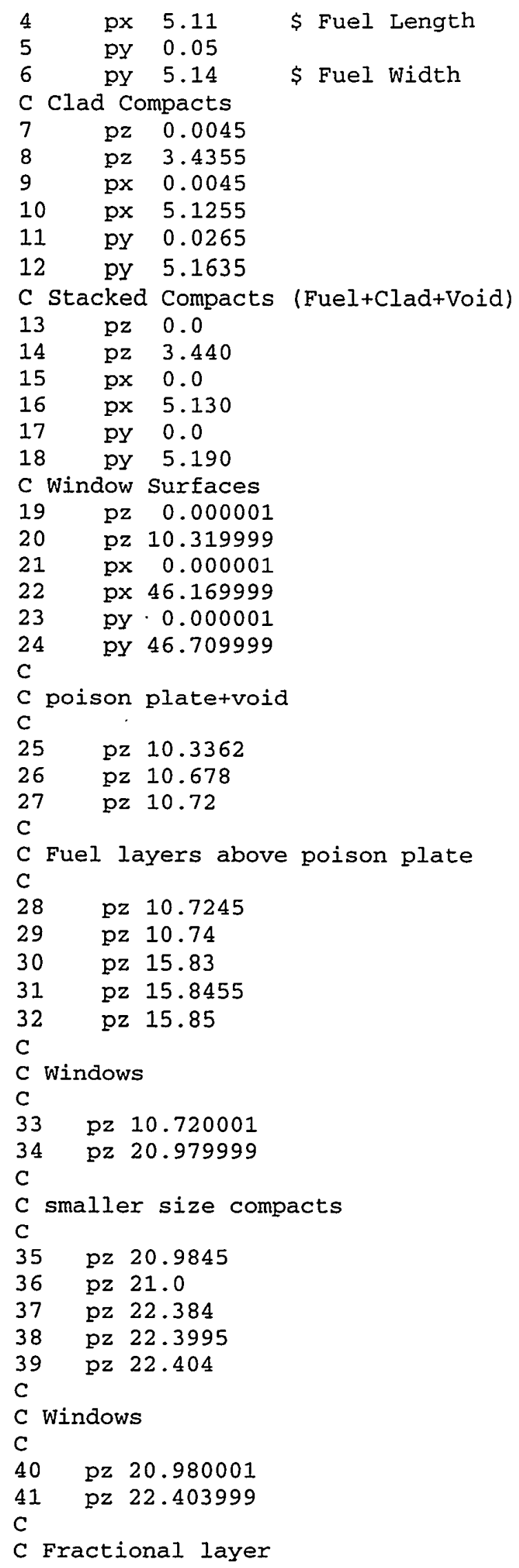




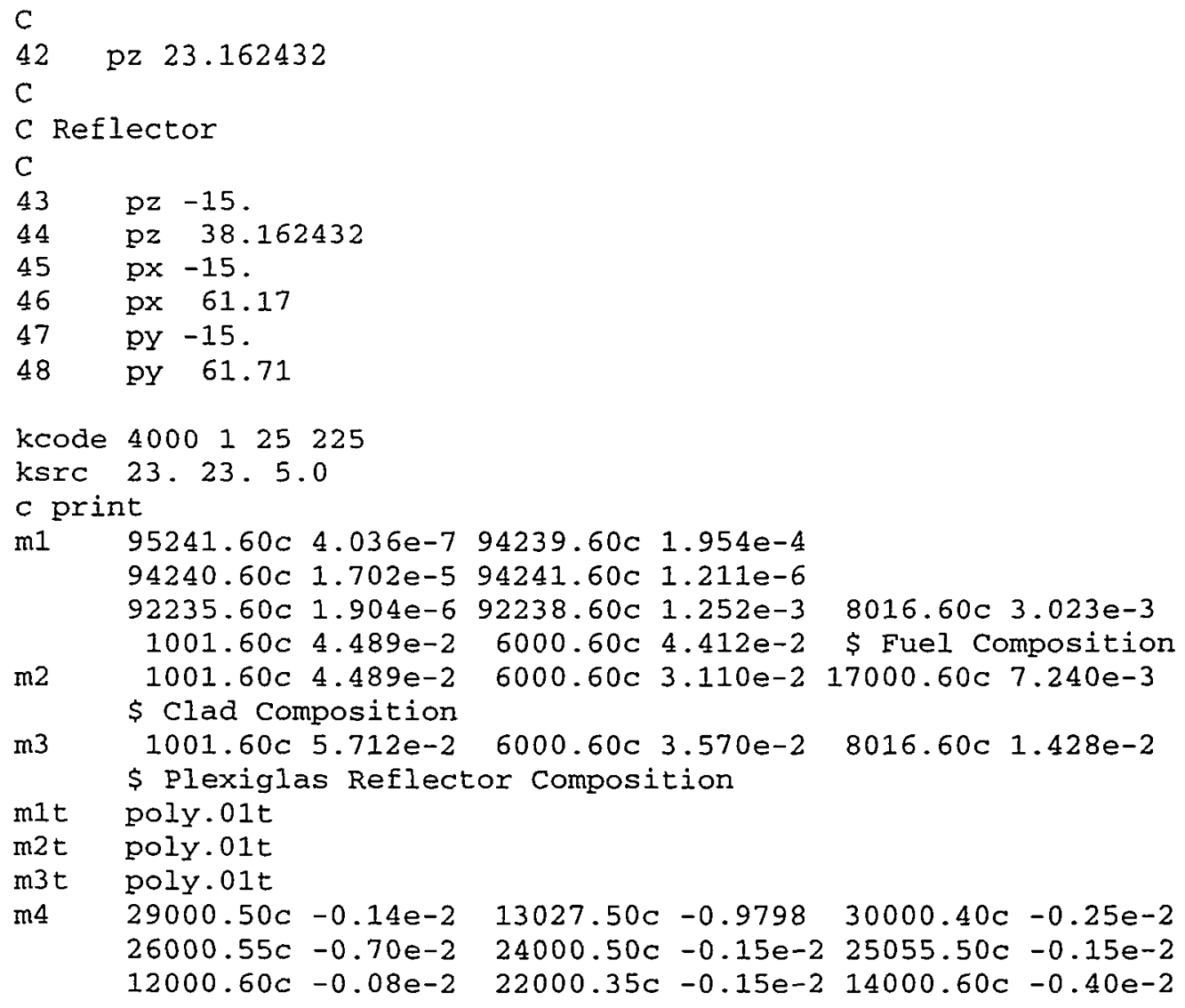




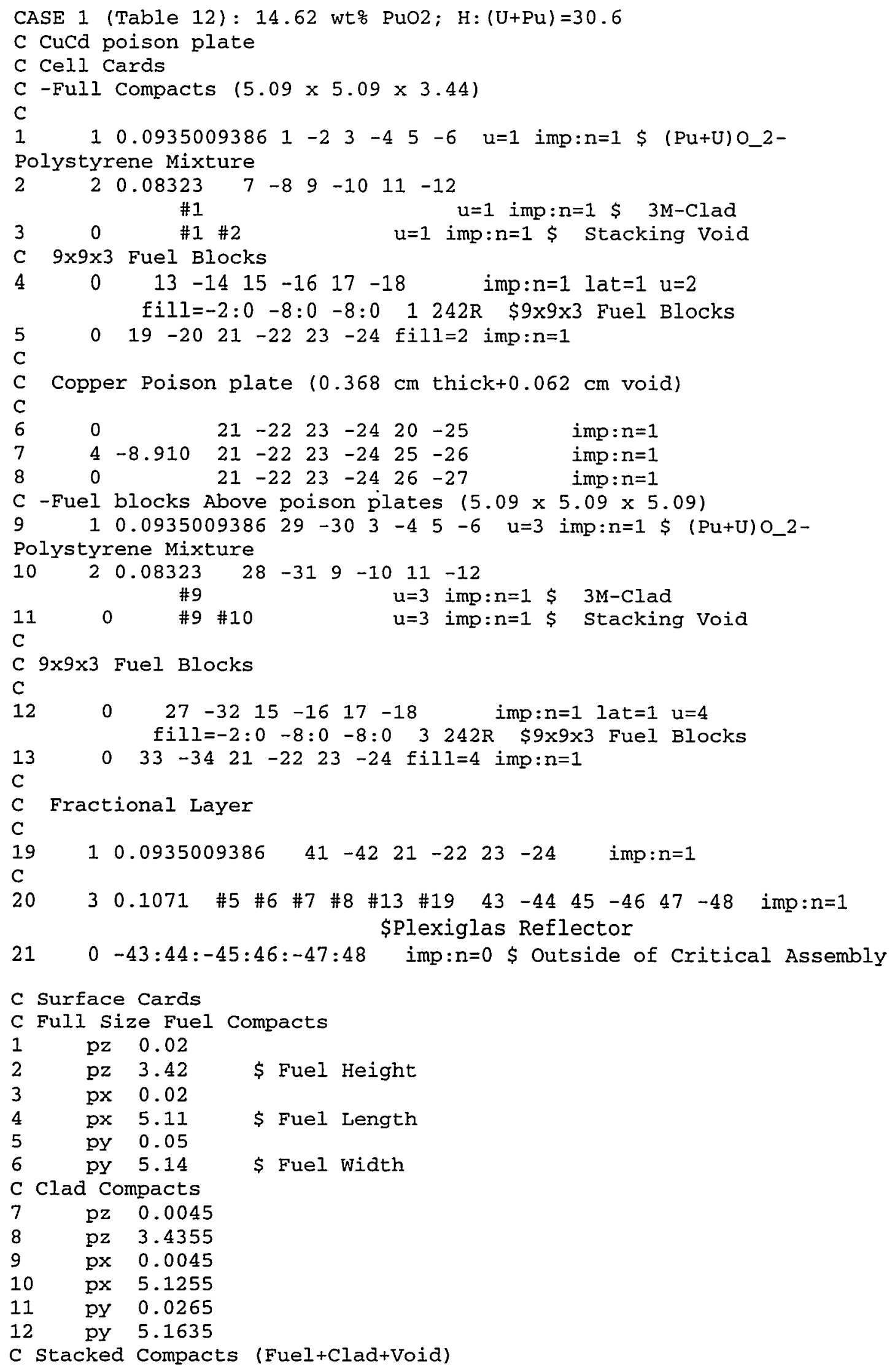




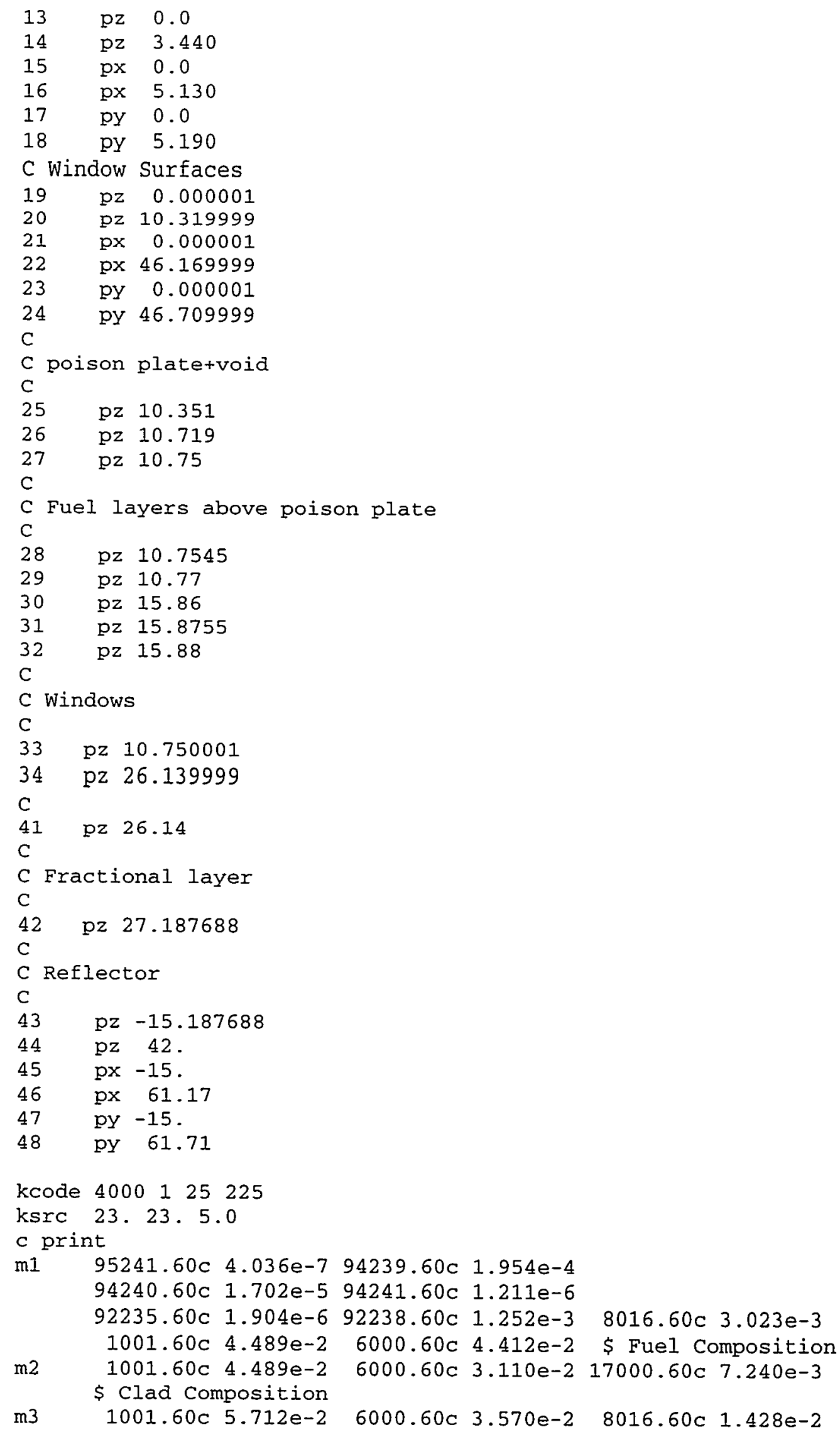


$\$$ Plexiglas Reflector Composition

m1t poly.01t

$\mathrm{m} 2 \mathrm{t}$ poly.01t

m3t poly.01t

m4 $\quad 29000.50 c-0.98685 \quad 48000.50 c-0.989 e-2 \quad 30000.40 c-7.0 e-5$

$50000.35 c-0.25 e-2 \quad 28000.50 c-0.01 e-2$

$26000.55 c-0.02 e-2 \quad 25055.50 c-9.0 e-5 \quad 5010.50 c-5.0 e-5$

$14000.60 c-4.0 e-5 \quad 8016.50 c-0.019 e-2 \quad 6000.50 c-2.0 e-5$ 
CASE 1: (Table 13) 30.3 wtq PuO2; $\mathrm{H}:(\mathrm{U}+\mathrm{Pu})=2.8$ - Copper Poison Plate C Cell Cards

C -Full Compacts $(5.09 \times 5.083 \times 5.09)$

C

$1 \quad \begin{array}{llllllllll}1 & 0.078287928 & 1 & -2 & 3 & -4 & 5 & -6 & u=1 & \text { imp: } n=1\end{array} \quad$ (Pu+U) O_2-Polystyrene Mixture

$\begin{array}{llllllllll}2 & 2 & 0.08323 & 7 & -8 & 9 & -10 & 11 & -12\end{array}$

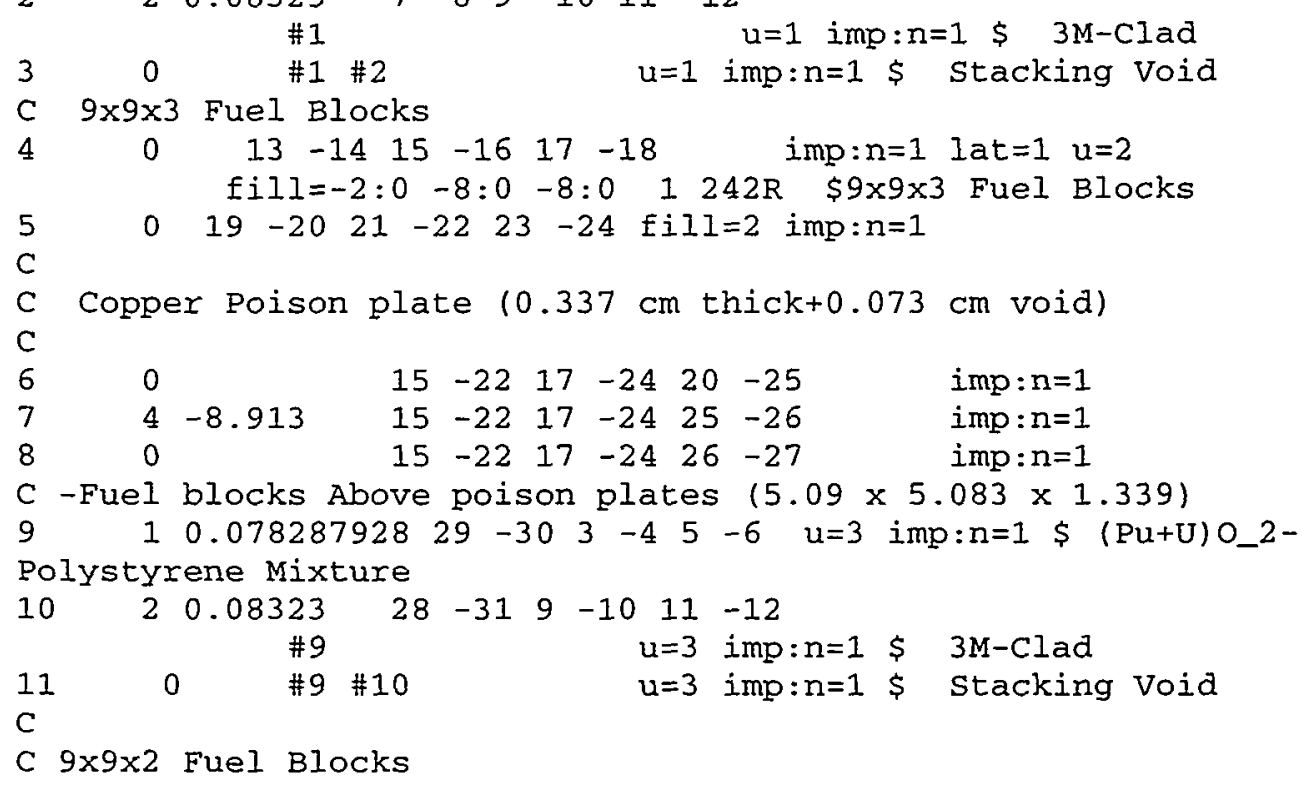

c

$12 \quad 0 \quad 27-32 \quad 15-16 \quad 17 \quad-18 \quad$ imp: $n=1$ lat=1 $u=4$

$13 \quad 0 \quad 33-34 \quad 21 \quad-22 \quad 23 \quad-24$ fill $1=4$ imp: $n=1$

C

C -Smaller Fuel blocks Above poison plates $(5.09 \times 5.083 \times 1.384)$

$\mathrm{C}$

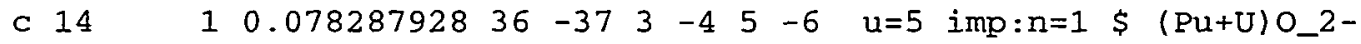
Polystyrene Mixture

$\begin{array}{lllllllll}\text { c } 15 & 2 & 0.08323 & 35 & -38 & 9 & -10 & 11 & -12\end{array}$

c \#14 $u=5$ imp: $n=1$ \$ $3 \mathrm{M}-\mathrm{Clad}$

c 160 \#14 \#15 u=5 imp:n=1 \$ stacking Void

C $9 \times 9 \times 2$ Fuel Blocks

$\begin{array}{llllllllll}\text { c } 17 & 0 & 34 & -39 & 15 & -16 & 17 & -18 & \text { imp: } n=1 & \text { lat }=1 \\ u\end{array}=6$

c fill $=-1: 0-8: 0-8: 0 \quad 5161 \mathrm{R} \quad \$ 9 \times 9 \times 2$ Fuel Blocks

$\begin{array}{lllllllllll}\text { c } 18 & 0 & 40 & -41 & 21 & -22 & 23 & -24 & \text { fill=6 imp: } n=1\end{array}$

C

C Fractional Layer

C

$19 \quad \begin{array}{lllllllll}1 & 0.078287928 & 41 & -42 & 21 & -22 & 23 & -24 & \text { imp: } n=1\end{array}$

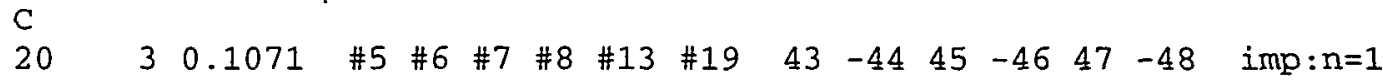

\$Plexiglas Reflector

$210-43: 44:-45: 46:-47: 48$ imp: $n=0$ \$ Outside of Critical Assembly

C Surface Cards

C Full Size Fuel Compacts

$1 \quad \mathrm{pz} \quad 0.014$

2 pz 5.104 \$Fuel Height

$\begin{array}{lll}3 & \mathrm{px} & 0.014 \\ 4 & \mathrm{px} & 5.104\end{array}$ 


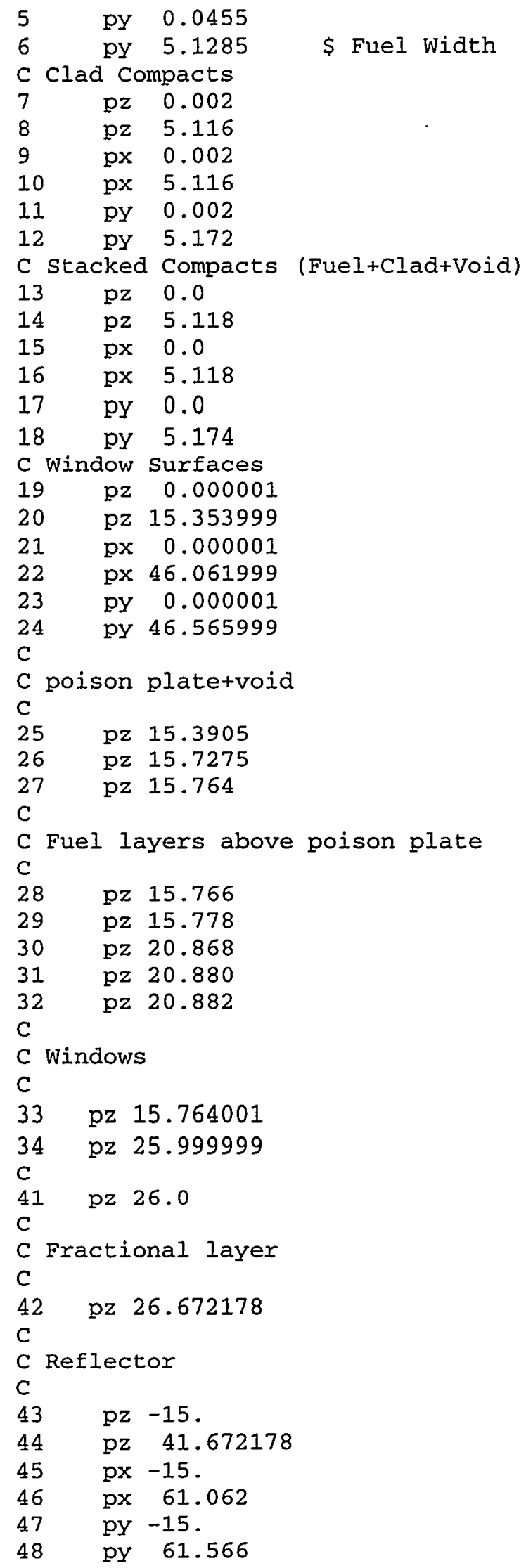


kcode 4000125225

ksrc 23.23. 5.0

c print

m1 $95241.60 \mathrm{c} 1.017 \mathrm{e}-5 \quad 94238.60 \mathrm{c} 2.288 \mathrm{e}-6 \quad 94239.60 \mathrm{c} 2.186 \mathrm{e}-3$

$94240.60 \mathrm{c} 2.927 \mathrm{e}-4 \quad 94241.60 \mathrm{c} 5.875 \mathrm{e}-5$ 94242.60c $6.751 \mathrm{e}-6$

$92235.60 c \quad 9.269 \mathrm{e}-6 \quad 92238.60 \mathrm{c} \quad 6.162 \mathrm{e}-3 \quad 8016.60 \mathrm{c} 1.864 \mathrm{e}-2$

$1001.60 \mathrm{c} 2.432 \mathrm{e}-2 \quad 6000.60 \mathrm{c} 2.660 \mathrm{e}-2$ \$ Fuel Composition

$\mathrm{m} 2 \quad 1001.60 \mathrm{c} \quad 4.489 \mathrm{e}-2 \quad 6000.60 \mathrm{c} \quad 3.110 \mathrm{e}-2 \quad 17000.60 \mathrm{c} 7.240 \mathrm{e}-3$

$\$$ Clad Composition

$\mathrm{m} 3 \quad 1001.60 \mathrm{c} 5.712 \mathrm{e}-2 \quad 6000.60 \mathrm{c} 3.570 \mathrm{e}-2 \quad 8016.60 \mathrm{c} 1.428 \mathrm{e}-2$ $\$$ Plexiglas Reflector Composition

mlt poly.01t

m2t poly.01t

m3t poly.01t

$\mathrm{m} 4 \quad 29000.50 \mathrm{c}-0.999626000 .55 \mathrm{c}-3.0 \mathrm{e}-5 \quad 30000.40 \mathrm{c}-1.0 \mathrm{e}-5$

$12000.60 c-1.0 e-5 \quad 14000.60 c-1.0 e-5 \quad 8016.60 c-3.0 e-4$

$6000.60 c-4.0 e-5$ 


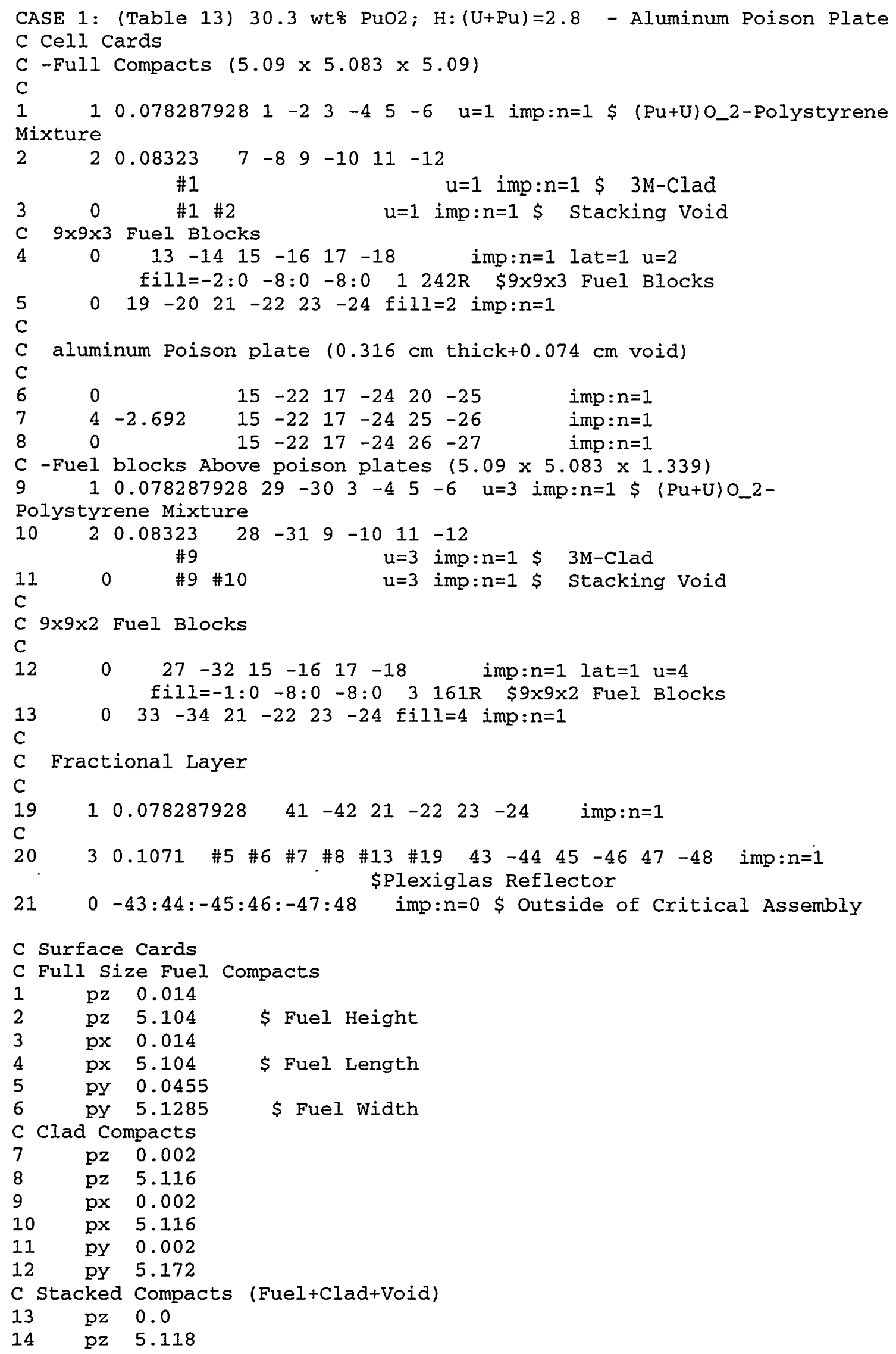




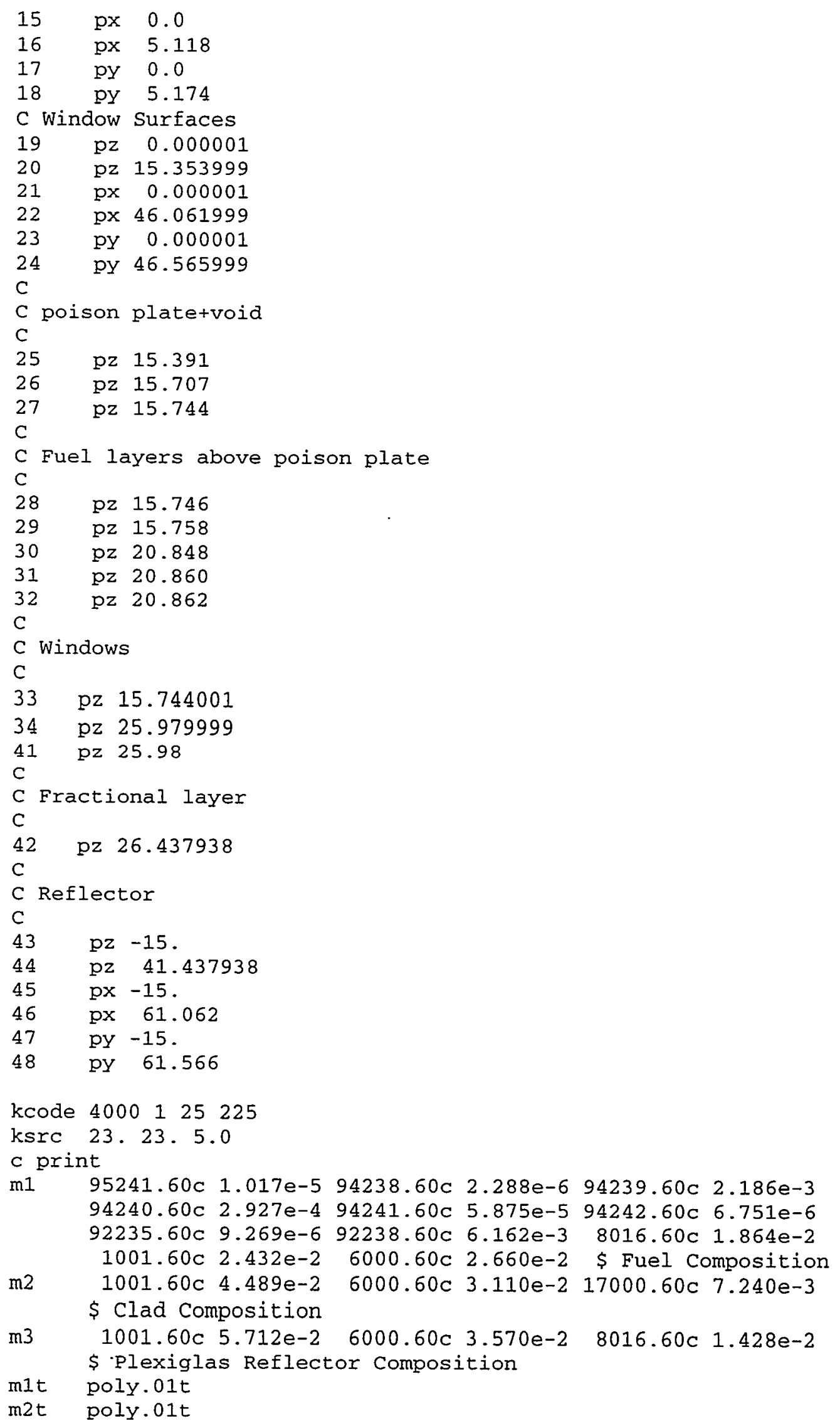




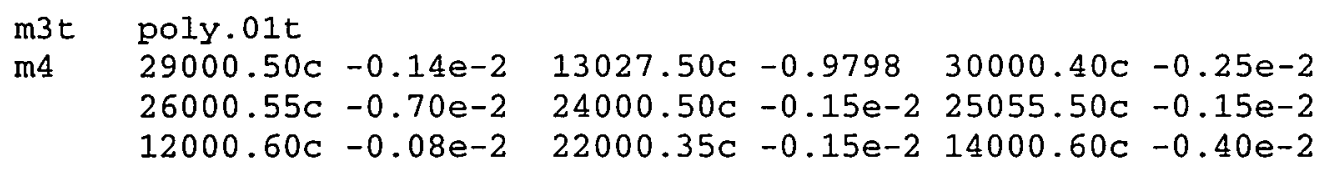




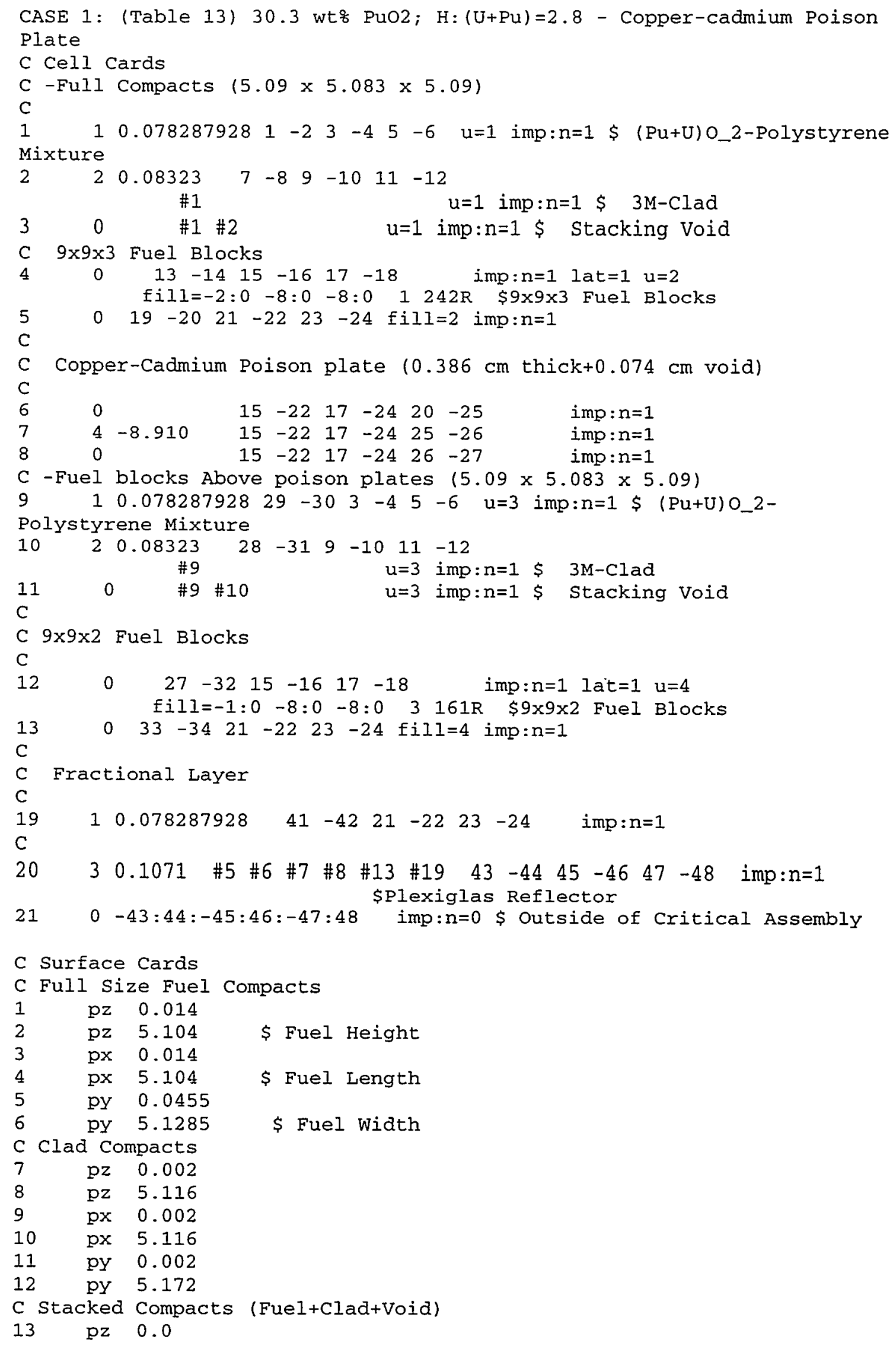




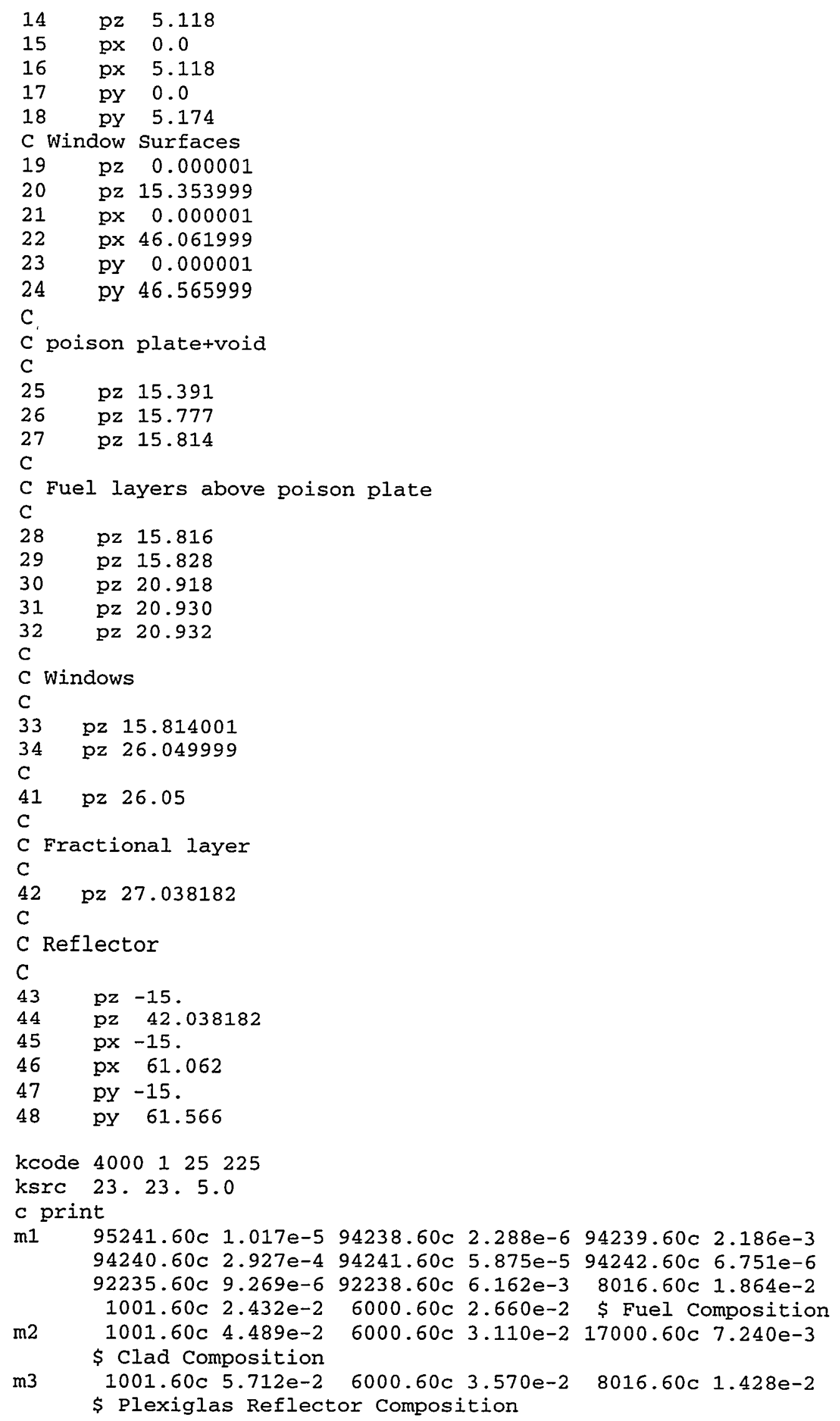




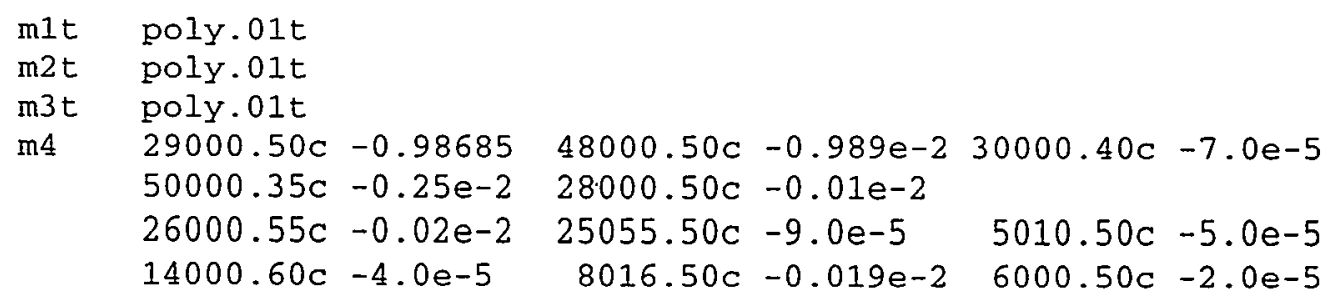




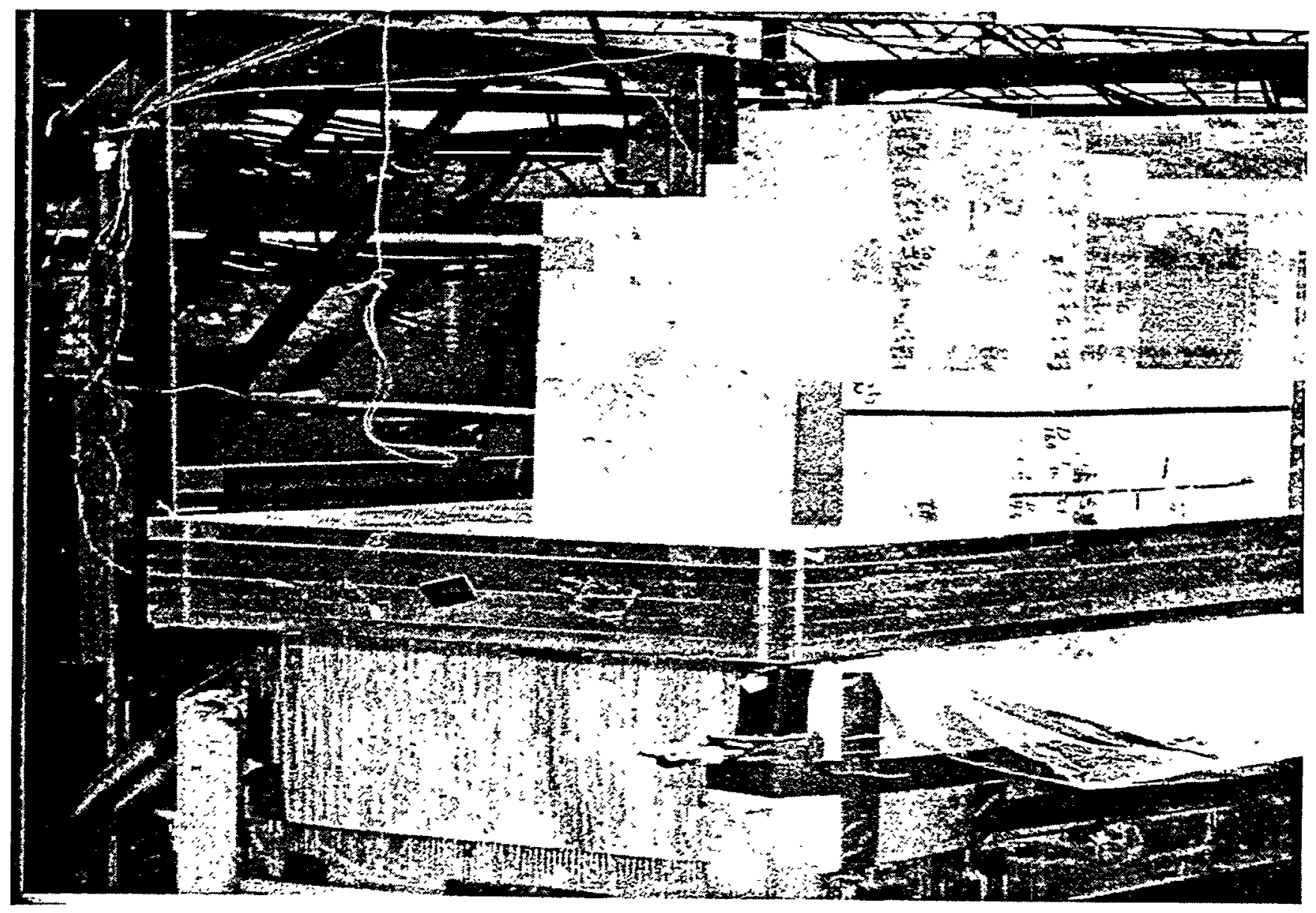

Fig. 1. Experimental assembly with part of the reflector removed. 


\section{INTERNAL DISTRIBUTION}

$\begin{aligned} \text { 1-5. } & \text { B. B. Bevard } \\ 6 . & \text { J. J. Carbajo } \\ 7 . & \text { E. D. Collins } \\ 8 . & \text { B. S. Cowell } \\ 9 . & \text { M. D. DeHart } \\ 10 . & \text { F. C. Difilippo } \\ 11 . & \text { M. D. Dunn } \\ 12 . & \text { R. J. Ellis } \\ \text { 13-17. } & \text { J. C. Gehin } \\ 18 . & \text { S. R. Greene } \\ 19 . & \text { T. W. Horning } \\ 20 . & \text { D. T. Ingersoll }\end{aligned}$

\author{
21. H. T. Kerr \\ 22. M. A. Kuliasha \\ 23. G. E. Michaels \\ 24. B. D. Murphy \\ 25. D. L. Moses \\ 26. C. V. Parks \\ 27-31. R. T. Primm III \\ 32. C. C. Southmayd \\ 33. B. S. Yarborough \\ 34. Central Research Library \\ 35-36. ORNL Laboratory Records (OSTI) \\ 37. ORNL Laboratory Records-RC
}

\section{EXTERNAL DISTRIBUTION}

38. N. Abdurrahman, College of Engineering, Dept. of Mechanical Engineering, University of Texas, Austin, TX 78712

39. M. L. Adams, Department of Nuclear Engineering, Texas A\&M University, Zachry 129, College Station, TX 77843

40. H. Akkurt, College of Engineering, Dept. of Mechanical Engineering, University of Texas, Austin, TX 78712

41. D. Alberstein, Los Alamos National Laboratory, MS-E502, P.O. Box 1663, Los Alamos, NM 87545

42. J. Baker, Office of Fissile Materials Disposition, U.S. Department of Energy, MD-3, 1000 Independence Avenue SW, Washington, DC 20585

43. J. B. Briggs, Idaho National Environmental and Engineering Laboratory, P.O. Box 1625-3855, Idaho Falls, ID 83415-3855

44. L. Holgate, Office of Fissile Materials Disposition, U.S. Department of Energy, MD-1/2, 1000 Independence Avenue SW, Washington DC 20585

45. A. Caponiti, Office of Fissile Materials Disposition, U.S. Department of Energy, MD-3, 1000 Independence Avenue SW, Washington DC 20585

46. K. Chidester, Los Alamos National Laboratory, MS-E502, P.O. Box 1663, Los Alamos, NM 87545

47. W. Danker, U.S. Department of Energy, MD-3, 1000 Independence Avenue SW, Washington DC 20585

48. T. Gould, Lawrence Livermore National Laboratory, P.O. Box 808, MS-L186, Livermore, CA 94551

49. L. Jardine, Lawrence Livermore National Laboratory, P.O. Box 808, MS-L166, Livermore, CA 94551

50. Dr. Alexander Kalashnikov, Institute of Physics and Power Engineering, 1 Bondarenko Square, Obninsk, Kaluga Region, Russia 249020

51-55. D. E. Klein, Associate Vice Chancellor for Special Engineering Programs, The University of Texas System, 210 West Sixth Street, Austin, TX 78701

56. J. O. Nulton, Office of Fissile Materials Disposition, U.S. Department of Energy, MD-3, 1000 Independence Avenue SW, Washington, DC 20585

57. S. L. Passman, Sandia National Laboratories, 1401 Wilson Blvd., Suite 1050, Arlington, VA 22209

58-62. Dr. Alexander Pavlovitchev, Russian Research Center "Kurchatov Institute," Institute of Nuclear Reactors VVER Division, VVER Physics Department, 123182, Kurchatov Square, 1, Moscow, Russia

63. K. L. Peddicord, Associate Vice Chancellor, Texas A\&M University, 120 Zachry, College Station, TX 77843-3133

64. G. Radulescu, Framatom Cogema Fuels, 1261 Town Center Drive, MS-423, Las Vegas, Nevada 89143

65. W. D. Reece, Texas A\&M University, Department of Nuclear Engineering, Zachry 129, College Station, TX 77843-3133

66. P. T. Rhoads, Office of Fissile Materials Disposition, U.S. Department of Energy, MD-4, 1000 Independence Avenue SW, Washington, DC 20585

67. J. Thompson, Office of Fissile Materials Disposition, U.S. Department of Energy, MD-4, 1000 Independence Avenue SW, Washington, DC 20585

68. F. Trumble, Westinghouse Savannah River Company, Building 730R, Room 3402, WSRC, Aiken, SC 29808

69. M. Yavuz, 7201 Wood Hollow Drive, \#475, Austin, TX 78731 